INDEPENDENT JOURNAL OF MANAGEMENT \& PRODUCTION (IJM\&P)

\title{
STOCKS MANAGEMENT THROUGH APPLICATION OF DEMAND FORECAST METHODS: A CASE STUDY
}

Lucas Lopes Filholino Rodrigues

Fatec Guarulhos, Brasil

E-mail: Iucasfilholino@hotmail.com

Igor Henrique Inácio de Oliveira

Fatec Guarulhos, Brasil

E-mail: igoroliveira06@outlook.com

Maurílio Fagundes Alexandre

Fatec Guarulhos, Brasil

E-mail: maurilio.alexandre@yahoo.com.br

Rodrigo Rodrigues Castorani

Fatec Guarulhos, Brasil E-mail: rodrigocastorani@hotmail.com

Celso Jacubavicius

Fatec Guarulhos, Brasil

E-mail: jacubavicius@uol.com.br

Submission: $31 / 03 / 2016$

Accept: 31/03/2016

\section{ABSTRACT}

The present study consists in assessing the feasibility of implementing demand forecasting techniques due to the optimization of inventory management, so that it is objective the reduce storage costs and to have the least amount of stationary material stock in a certain period. Data analysis was for application of techniques based on the real case of a multinational company in the segment of electronic and digital systems in the infrastructure area, which operates in the metropolitan region of São Paulo.

The study aims to evaluate the behavior of the studied company demand, in order to demonstrate some forecast models for it and thus being able to identify the most appropriate method to get the highest possible degree of assertiveness. 
At a first moment, there will be a survey of data concerning the company's historical demand, including the forecast used at the latest period, and then to survey the state of the art discussed topic, in order to clarify the reader, and as a result: the analysis of the collected data and the implementation of demand forecasting techniques presented in bibliographic references.

After performing an analysis of the naive method demand forecasting practiced by the company, was carried out the application of different forecasting methods and found out that the method that best suits the given demand was the moving average, which provided the optimization of cost of storage in approximately $63 \%$ of the one presented by the naive method and also a gain of approximately $R \$$ $2,000,000.00$ during the studied period, thus proving the effectiveness of demand forecasting application for inventory management.

Keywords: Forecast; Demand; Management; Inventory; Optimization.

\section{INTRODUCTION}

Currently is possible to see that the set of uncertainties in a business segment is proportionally linked to the chances of obtaining negative results, both financially as to the level of service. This is a factor that is evident even to organizations working in the design and production of consumer goods. Due to these aspects, demand forecasting techniques are of fundamental importance to reduce that risk in order to achieve positive results and profits.

The impacts caused by the development of a demand forecasting are crucial to the survival of businesses: on this account, mistakes can cause the end of its existence; and accurate results can leverage profits and ensure its expansion and market gain. Due to this fact that there are several techniques to achieve the demand forecast and several technological features that make accurate results, based whenever possible on data analysis using quantitative methods.

This is a research in which will be presented, on implementation and evaluation of different quantitative methods of demand forecasting, for an organization that produces electrical durable goods in the construction industry, so that the central objective of the study is to understand the demand behavior and identify the most suitable method to get the forecast with the highest degree of assertiveness as possible. 
DOI: $10.14807 /$ ijmp.v7i5.458

$A B C$ Group will be used as the base of this search, so that its operation happens in approximately 180 countries, where electronic and digital systems are developed in the building infrastructure area.

\section{PROBLEM}

The instability of the relation of excess inventory and the lack of resources is a intrinsically detrimental factor to the finances of a company, and in respect of a particular product the company studied, it was realized that there is, in various times, material in excess due to the need to meet the demand, a situation that leads to inventory build-up resulting in impacting of costs in the financial statement for the period.

\section{JUSTIFICATION}

Due to the presented problem, it is of considerable importance to develop a demand forecast which can stabilize the flow of materials to greater assertiveness in meeting demand, since for the product in question, after survey and analysis of the actual demand data and the expected one, there was excess on average about 5.5\% of the material required to meet demand.

\section{HYPOTESIS}

The application of a demand forecasting method can balance the ratio of surplus and shortages, providing to the company the ability to spend less on stocks without the risk of not meeting the demand.

\section{OBJECTIVE}

Evaluate the behavior of the demand in the studied company, in order to demonstrate some forecast models for such and thus being able to identify which method is the most appropriated one to provide the highest possible degree of assertiveness.

\section{METHODOLOGY}

According to Gil (2008), this study is a quantitative research, once that will be used mathematical data and models in order to get the results, and is exploratory. Still according to the author, this method may involve people with some experience in the subject, interviews and literature, keeping in view the objective of analyzing the 
DOI: 10.14807/ijmp.v7i5.458

existing process without direct participation in it, where the following steps are performed:

- Survey of data regarding the company's demand in concerning to the occurrences studied, including the forecast used by this one in a given period;

- Survey of the state of the art on the theme approached, in order to elucidate the reader on the subject;

- Description of the methodology used by the company studied;

- Demonstration of the relation between the technical literature and quoted ones;

\section{THEORETICAL FOUNDATION}

\subsection{Demand Forecasting}

Initially the horizon of the demand planning Buffa \& Sarin (1987) classifies that the forecasts can be short-term, probably related to inventory controls; can be medium-term referring to planning production; and long-term plans, usually used in the company's strategic level to plan the growth of the business.

Considering the need for accuracy at the time of acquisition and manufacturing, in addition to the uncertainties that involve the demands in general, companies cannot rely on a chance to make possession of their inputs, materials and goods, since they need to ensure that the amount acquired is the closest to be used, limiting or preventing faults and leftovers. Technological advances brought business development techniques, philosophies and policies focused on increasing the degree of assertiveness on the management of inventory, transportation and other activities of logistics competence.

The forecast of demand is one of these techniques, so that can be defined by the number of activities that estimate the amount of resources for future needs based on past occurrences (DIAS, 1990), as agreed Boland (1985) arguing that "forecasting can be understood as a projection or extrapolation of past trends.".

Well elaborate demand forecasts can provide to a company successful integration of production processes, distribution and inventory management with 
lower costs well as greater objectivity and front flexibilities to extra searches. Diaz \& Saucer (2003) say that the forecast demand is a critical step for all players of a supply chain because of the complexity and uncertainty of its activities, in addition to Makridakis (1988), noting that it is through demand forecasting that companies make strategic decisions, structure plans or take any action that relates future events.

Concerning the methodology, the forecast demands may occur in qualitative ways considering expert opinions, capable of critical analysis of a history of occurrences, or quantitative, that are more accurate and based on mathematical and statistical systems, but without sensitivity to differentiation of demand scenarios.

There are also researchers trying to combine the two methodologies, developing a model based on historical data and then quantifying this data, generating mathematical analyzes that are more accurate than any individual forecast (MOREIRA, 2009). The next topics will demonstrate some of the leading demand forecasting methods, which are used in this study.

\subsection{Linear Regression}

According to Neufeld (2003), the linear regression analyzes the relation between two variables. The correct data for this method consists in observations with different measures each. So has been an independent variable (variable $\mathrm{x}$ ) and a dependent one (variable y), considering that the first variable causes changes in the second. This method is one of the most used ones. The authors Krajewski, Ritzman and Malhotra (2009) complemented this claim and pointed out to the possibility of the trend line training that enables statements within the studied horizon.

The application of the method is given by the formula demonstrated below:

$$
\begin{aligned}
Y & =a+b X \quad b=\frac{n\left(\sum X Y\right)-\left(\sum X\right)\left(\sum Y\right)}{n\left(\sum X^{2}\right)-\left(\sum X\right)^{2}} \\
& a=\frac{\sum Y-b\left(\sum X\right)}{n} \\
Y & =\text { Variável Dependente; } \\
a & =\text { Intercepto no eixo da variável Independente }(\mathrm{Y}) ; \\
b & =\text { Coeficiente angular; } \\
X & =\text { variável Independente; } \\
n & =\text { número de periodos observados. }
\end{aligned}
$$


DOI: 10.14807/ijmp.v7i5.458

\subsection{Simple Average}

This method although simple has certain degree of assertiveness. He forecasts future demand as the average of the demands from previous periods. This type of technique is not suitable for series that present trend and / or seasonality and should only be used to forecast a period ahead (WANKE; JULIANELLI, 2006). Because the old values have the same weight the new values obtained in the course of time, this method does not respond quickly to changes in the level of the sample.

Below is demonstrated the formula of this method:

$$
\begin{gathered}
P_{t+1}=\frac{\sum_{t=1}^{n} R_{t}}{n} \\
P_{t+1} \quad \text { - Previsão para o próximo periodo; } \\
R_{t} \text { - Valor real observado no periodo } t ; \\
n \quad \begin{array}{l}
\text { - Número de periodos no histórico de vendas } \\
\text { passadas }
\end{array}
\end{gathered}
$$

\subsection{Simple Moving Average}

Simple Moving Average (SMA) has strength in continuous demand variations and therefore its disability is in cases of intermittent demands. (EAVES; KINGSMAN, 2004; PORRAS; DEKKER, 2008; TEUNTER; DUNCAN, 2009). This method is recommended for short-term forecasts where the components of the trend and seasonality can be ignored or non-existent. (MAKRIDAKIS; WHEEL WRIGHT; HYNDMA, 1998).

This technique is not indicated to the series having seasonality or trend, because the forecast tend to become outdated due to this method, when used in fewer periods, shows higher impact by including new data, and the weights assigned to these are the same for all sample data.

This is the most used model by companies in general, because of the simplicity and the need for a reduced history data, analyzing a very short period of the process so that the number of observations in each average calculation remains 
DOI: $10.14807 /$ ijmp.v7i5.458

constant and is stipulated in a way that tries to eliminate as best as we can the trend and seasonality components. "(CHAMBERS; MULLICK; SMITH, 1971; ARCHER, 1980; MAKRIDAKIS; WHEELWRIGHT; HYNDMAN, 1998).

Below is demonstrated the formula of this method:

\subsection{Double Moving Average}

According to the authors Wanke and Julianelli (2006), the dual moving average method can be considered more efficient when compared to the simple moving average, by adhering to samples with a tendency. However, both methods assume that the recent values are just as important as the earliest to define the future value, a fact that contradicts practical situations. In this case, the simple moving average method is applied twice, once in the original data and then the data resulting from this first application.

Below is demonstrated the formula of this method:

$$
\mathrm{P}_{t+p}=a_{t}+b_{t} p
$$

Onde:

$$
\begin{aligned}
& \mathrm{P}_{t+p}=\text { previsão para o próximo } p \text { período futuro; } \\
& p=\text { número de períodos à frente a ser previsto; } \\
& \mathrm{R}_{t}=\text { valor real observado no período } t \\
& n=\text { número de períodos considerados no cálculo da previsão (média móvel) } \\
& \mathrm{M}_{t}=\frac{\mathrm{R}_{t}+\mathrm{R}_{t-1}+\mathrm{R}_{t-2}+\ldots+\mathrm{R}_{t-n+1}}{n} \\
& \mathrm{M}_{t}^{\prime}=\frac{\mathrm{M}_{t}+\mathrm{M}_{t-1}+\mathrm{M}_{t-2}+\ldots+\mathrm{M}_{t-n+1}}{n} ; \\
& \qquad a_{t}=2 \mathrm{M}_{t}-\mathrm{M}_{t}^{\prime} ; \\
& b_{t}=\frac{2}{n-1}\left(\mathrm{M}_{t}-\mathrm{M}_{t}^{\prime}\right) .
\end{aligned}
$$

\subsection{Method Of Simples Exponential Damping}

According to Corrêa and Corrêa (2006), the Simple Exponential method is the weighted average of past data, so that the weight decreases according to the antique of data: the older the value, less is its impact in the calculation. 
DOI: 10.14807/ijmp.v7i5.458

This is a different method than the others explained, because here is considered a differentiation among the values in each period analyzed. Thus, through the Damping Coefficient is possible to assign light or heavier weights to the most recent values, but as recent is the occurrence the bigger will be its impact in the calculation. (SOUZA; SAMOHYL; MIRANDA, 2008).

The Mathematical formula for this method is demonstrated below:

$$
\begin{gathered}
P_{t+1}=\alpha R_{t}+\alpha(1-\alpha) R_{t-1}+\alpha(1-\alpha)^{2} R_{t-2}+\ldots \\
\text { Ou ainda, } \\
P_{t+1}=\alpha R_{t}+(1-\alpha) P_{t}
\end{gathered}
$$

Onde:

$\mathrm{P}_{\mathrm{t}+1} \rightarrow$ Previsão para o período $t+1$;

$\alpha \rightarrow$ Coeficiente de amortecimento $\alpha \in[0,1]$;

$\mathrm{R}_{\mathrm{t}} \rightarrow$ Demanda real ocorrida em $\mathrm{t}$.

\subsection{Holt Method Or Double Exponential Damping}

According to Gaither and Frazier (2001), this method is indicated to be used with series and tendencies, possessing two Damping coefficients utilized for tendency and level sample. The first coefficient is represented by $\alpha$ and is referent to the level, and the second is represented by $\beta$ and refers to the series of trend.

The Mathematical formula for this method is demonstrated below:

$$
\begin{aligned}
& N_{t}=\alpha R_{t}+(1-\alpha)\left(N_{t-1}+T_{t-1}\right) \\
& T_{t}=\beta\left(N_{t}-N_{t-1}\right)+(1-\beta) T_{t-1} \\
& P_{t+p}=N_{t}+p T_{t}
\end{aligned}
$$

$N_{t}:$ Componente nível

Onde: $\quad T_{t}:$ Componente tendência

$\beta$ : Coeficiente de amortecimento para a estimativa da tendência $-0 \leq \beta \leq 1$

$\alpha$ : Coeficiente de amortecimento $-0 \leq \alpha \leq 1$ 
DOI: 10.14807/ijmp.v7i5.458

\section{CASE STUDY}

The $A B C$ Group is one of the largest companies in the electronic and digital systems segment in the infrastructure area, owns several brands with more than four thousand patents and one hundred seventy thousand items, is present in over one hundred and eighty countries. It is emphasized that due to the high flow material handling, it can be said that inventory management is crucial to the organization of products and control of entrance and exit of goods, thus avoiding losses and obtaining the profits of such stock.

\subsection{Case}

The product chosen for study holds about $20 \%$ of the total turnover of the company, however, comparing with other items developed by the company, this one has a low value at the time of sale, which refers to $R \$ 2.89$, besides high costs of storage due to volume, representing the value of $R \$ 1.20$ per piece within one month. By fidelity issues, the company adopts policies that force to meet all periodic supply for this product, so in situations of lack of products it is necessary to provide extra production of the items, a process that represents additional cost of $15 \%$ of the original value of the production cost that is, each unit that need to be added to the amount provided will have the cost of $R$ \$1.02.

The company adopted a simple quantitative method, so that to anticipate the demands of the next period, the management was based on the same period last year, but with the adding $10 \%$ of the total value of items sold. It will be shown below the mathematical model used by the company to make such a prediction. This method is defined as naive method and is characterized by simple use of historical data as happened in the previous period or simply a correction factor for the period. (BARBIERI; MACHILINE, 2009).

From the table below will be shown the actual demand of the period to which it tried find, besides the forecast made by the company based on the previous calculation and the error rate caused by the prediction. 
INDEPENDENT JOURNAL OF MANAGEMENT \& PRODUCTION (IJM\&P)

http://www.ijmp.jor.br

v. 7, n. 5, Special Edition IFLOG 2015

ISSN: 2236-269X

DOI: 10.14807/ijmp.v7i5.458

Table 1: Average error obtained by the naive method

\begin{tabular}{|c|c|c|}
\hline Real & Forecast & Error (\%) \\
& & \\
\hline 550000 & 585000 & $\mathbf{5 , 9 8}$ \\
\hline 430000 & 450000 & $\mathbf{4 , 4 4}$ \\
\hline 390000 & 430000 & $\mathbf{9 , 3}$ \\
\hline 400000 & 450000 & $\mathbf{1 1 , 1 1}$ \\
\hline 330000 & 355000 & $\mathbf{7 , 0 4}$ \\
\hline 300000 & 310000 & $\mathbf{3 , 2 3}$ \\
\hline 310000 & 340000 & $\mathbf{8 , 8 2}$ \\
\hline 400000 & 428000 & $\mathbf{6 , 5 4}$ \\
\hline 420000 & 500000 & $\mathbf{1 6}$ \\
\hline 425000 & 400000 & $\mathbf{- 6 , 2 5}$ \\
\hline 450000 & 460000 & $\mathbf{2 , 1 7}$ \\
\hline 400000 & 390000 & $\mathbf{- 2 , 5 6}$ \\
\cline { 2 - 3 } & Média & $\mathbf{5 , 4 9}$ \\
\hline
\end{tabular}

As noted, in one of the periods there was no excess material needed, a situation which consequently limited the company about the efficiency and accuracy of its stock, in addition to providing impactful cost of such storage. The costs of the previous forecast errors are listed in the table below:

Table 2: Total Cost storage obtained

\begin{tabular}{|l|c|c|c|}
\hline Real & Forecast & Accumulated Stock & Storage Cost \\
\hline 550000 & 585000 & 35000 & $\mathrm{R} \$ 42.000,00$ \\
\hline 430000 & 450000 & 55000 & $\mathrm{R} \$ 66.000,00$ \\
\hline 390000 & 430000 & 95000 & $\mathrm{R} \$ 114.000,00$ \\
\hline 400000 & 450000 & 145000 & $\mathrm{R} \$ 174.000,00$ \\
\hline 330000 & 355000 & 170000 & $\mathrm{R} \$ 204.000,00$ \\
\hline 300000 & 310000 & 180000 & $\mathrm{R} \$ 216.000,00$ \\
\hline 310000 & 340000 & 210000 & $\mathrm{R} \$ 252.000,00$ \\
\hline 400000 & 428000 & 238000 & $\mathrm{R} \$ 285.600,00$ \\
\hline 420000 & 500000 & 318000 & $\mathrm{R} \$ 381.600,00$ \\
\hline 425000 & 400000 & 293000 & $\mathrm{R} \$ 351.600,00$ \\
\hline 450000 & 460000 & 303000 & $\mathrm{R} \$ 363.600,00$ \\
\hline 400000 & 390000 & 293000 & $\mathrm{R} \$ 351.600,00$ \\
\hline \multicolumn{2}{|c|}{} & Total & $\mathrm{R} \$ 2.802 .000,00$ \\
\hline
\end{tabular}

As a result, in order to have a better observation of the problem was developed a graphic representation with the relation between the demand and the forecast made by the company. 
DOI: $10.14807 /$ ijmp.v7i5.458

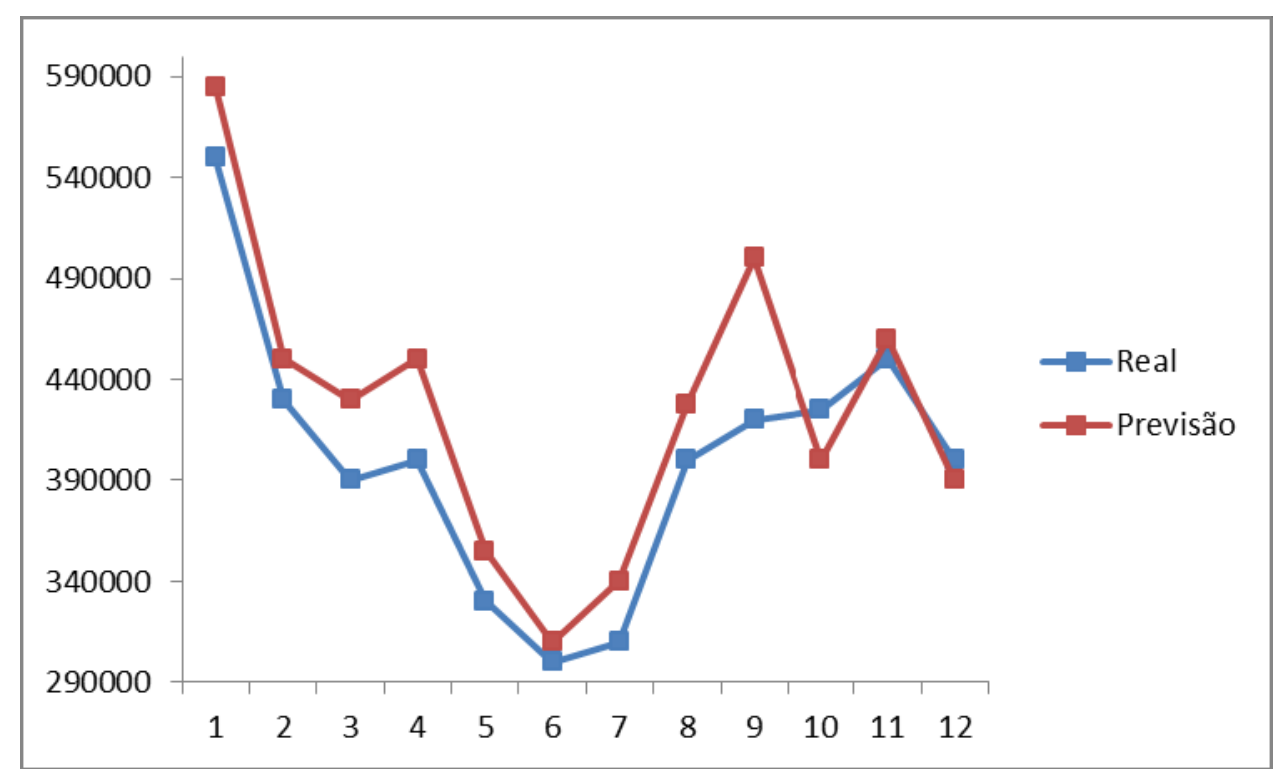

Figure 1: Graphical representation of the relationship between forecast and actual demand.

After analyzing the results obtained by the company in total period observed, it's possible to see that only due to the high volume stored during the year there was a total cost of $R \$ 2,802,000.00$, that is a significantly value, since the amount is about $40 \%$ of all profits obtained in the period on this product.

\subsection{Application}

As explained before, the company needs a new demand forecasting technique able to reduce the alarming costs to better economic performance. Thus, the aforementioned techniques were applied in order to find a better solution to the problem.

The application of such techniques took place in accordance with the formulas shown above, so that how to get the results of storage costs and their impacts, is the same that tab of the presentation of the method used by the company, as Table 3 .

After the application of the concept and the mathematical techniques for each method of forecast, was possible to develop the below table, with the results and others data about the operation. 
INDEPENDENT JOURNAL OF MANAGEMENT \& PRODUCTION (IJM\&P) http://www.ijmp.jor.br

v. 7, n. 5, Special Edition IFLOG 2015

ISSN: 2236-269X

DOI: 10.14807/ijmp.v7i5.458

Table 3: General demonstrative of results.

\begin{tabular}{|c|c|c|c|c|c|}
\hline & $A B C$ & Simple Average & Moving Average & $\begin{array}{l}\text { Simple Exponential } \\
\text { Smoothing }\end{array}$ & Holt \\
\hline EA (\%) & 5,50 & 2,77 & 1,47 & 5,94 & 3,64 \\
\hline $\mathbf{R}$ & $\mathrm{R} \$ 13.886 .450,00$ & $R \$ 13.886 .450,00$ & $R \$ 13.886 .450,00$ & $\mathrm{R} \$ 13.886 .450,00$ & $R \$ 13.886 .450,00$ \\
\hline SC & $\mathrm{R} \$ 2.802 .000,00$ & $3.810 .986,15$ & $1.035 .000,00$ & $\mathrm{R} \$ 4.372 .412,00$ & $\mathrm{R} \$ 2.753 .894,74$ \\
\hline PC & $\mathrm{R} \$ 4.537 .220,00$ & $4.451 .767,80$ & $4.352 .100,00$ & $\mathrm{R} \$ 4.575 .385,08$ & $\mathrm{R} \$ 4.447 .357,40$ \\
\hline TP & $\mathrm{R} \$ 6.547 .230,00$ & $R \$ 5.623 .696,05$ & $\mathrm{R} \$ \mathbf{8 . 4 9 9 . 3 5 0 , 0 0}$ & $\mathrm{R} \$ 4.938 .652,92$ & $R \$ 6.685 .197,86$ \\
\hline CPR & $42,80 \%$ & $67,77 \%$ & $12,18 \%$ & $88,53 \%$ & $41,19 \%$ \\
\hline & \multicolumn{5}{|c|}{$\begin{array}{c}\text { EA }=\text { ERROR AVERAGE } \\
\text { R }=\text { RECIPE } \\
\text { SC }=\text { STORAGE COSTS } \\
\text { PC = PRODUCTION COSTS } \\
\text { TP }=\text { TOTAL PROFITS } \\
\text { CPR = COST IN PROFITS REPRESEN }\end{array}$} \\
\hline
\end{tabular}

The figure shows the recipe $(R)$ consisting of the period billing amount; the Total Storage Cost (TAC) that indicates the reason of unitary cost to storage for all goods that must be kept in inventory in function of the determined forecast; the Cost Total production (CPT), established by multiplying the suggested volume in the given forecast, for the unit cost of production, besides the total profit of the period (LPT) that quantifies the value obtained in the difference between revenue and costs presented for each of the related forecasts; and, finally, the average error of each forecast (EM). It is noteworthy that, after application of the linear regression method, it was noted an average of $16.9 \%$ error, a result that makes it completely not workable to use this technique to the problem in question. In this way, this one was removed of the demonstration of analysis.

Analyzing the results, it is observed that the techniques of simple average and simple exponential represent results below what was presented by the naive technique, put into practice by the studied company, in such a way representing respectively $68 \%$ and $89 \%$ of the total profit obtainable from such applications, conditions that make their use impractical.

As for the Holt technique, there is a small positive change in the result as compared to naive technique. In percentage, was obtained approximately $2 \%$ gain in total income for the period, but also presents considerable amounts of products that would be stopped in stock, so that the storage value represents approximately $41 \%$ of profit. 
DOI: 10.14807/ijmp.v7i5.458

Considering the proposed methods, the one that presents the best solution for forecasting is the method of moving average, because besides presenting an average error in just $1.47 \%$, reduced by $63 \%$ storage costs, when compared with the technique used by the company and thus increased profit by approximately $\mathrm{R} \$$ $2,000,000.00$. Participation of storage costs in the profit obtainable from the application of this technique corresponds to only about $12 \%$, is significantly lower than those achieved by the studied company.

In figure 3, one can see graphically that the method of moving average has greater adhesion to the company's demand, since the correlation between these figures is shown with a high degree of similarity, thus demonstrating that with the fall of the error forecast, more assertive will be the method. The reduction of about $4 \%$ in the average for in this demand forecasting method boosted the company's profit, without any change in the price of the product, so it may be said that the organization's procurement process has become more efficient.

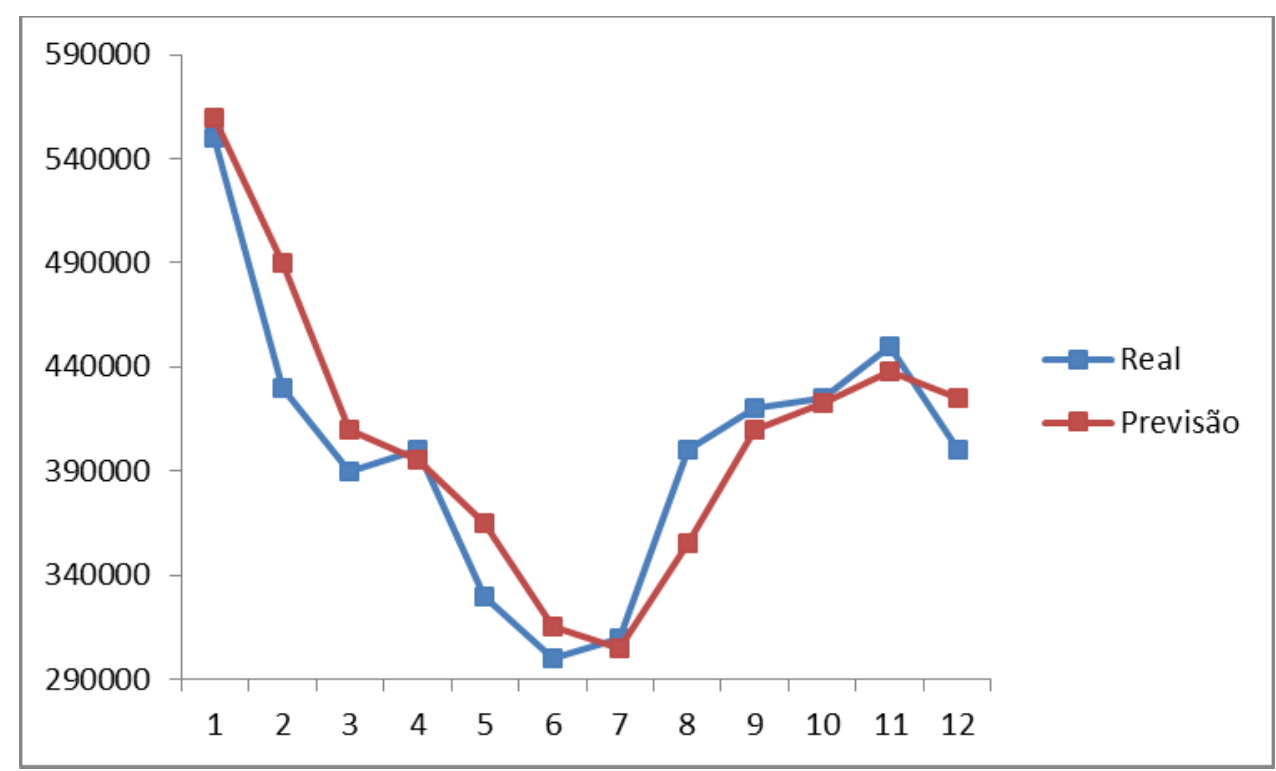

Figure 2: Graphic representation of forecast x moving average

\section{FINAL CONSIDERATIONS}

At the end of the survey, was possible to note that the company had high levels of inventory, which represents an important problem at its financial health. The company still had used inefficient methods to promote the demand forecasting, supply chain and to guide the production, which explain the existence of a lack in the supply needs and the supply storage. 
INDEPENDENT JOURNAL OF MANAGEMENT \& PRODUCTION (IJM\&P)

http://www.ijmp.jor.br

v. 7, n. 5, Special Edition IFLOG 2015

ISSN: 2236-269X

DOI: 10.14807/ijmp.v7i5.458

There are techniques to forecasting the warehouse demand, with proved efficacy and knew by the scientific community. Several techniques were applied to the real data, and the results were analyzed to best fit the supply chain itself.

As shown in this survey, was possible to indicate that the moving average was the best-fitted method to forecast the needed level of storage, which decreased the levels of the error compared with the naive technique. The usage of the moving average was able to reduce the cost of storage in $63 \%$ and increase the profit in $\mathrm{R} \$$ $2.000 .000,00$, when compared with the naïve method at the time of the study.

Finally, can be emphasized that the choice of a technic as the moving average does not eliminate the possible choice and use of another forecast technic, however, in this case, the moving average technic demonstrates that it is adequate to fit the company demand and be a good solution to increase the company profit.

\section{REFERENCES}

BARBIERI, J. C.; MACHLINE, C. (2009) Logística Hospitalar: teoria e prática. 2.ed. rev. e atual. São Paulo: Saraiva.

BOLAND, J. J. (1985) Forecasting water use: A tutorial. Computer Application sinwater Resouces. Edited by H. C. Torno, Buffalo, Nova York, p. 907-916.

BUFFA, E. S.; SARIN, R. K. (1987) Modern production/operations management. 8. ed. Los Angeles: John Wiley \& Sons.

CORRÊA, H. L.; CORRÊA, C. A. (2006) Administração da Produção e Operações. São Paulo: Atlas.

DEKKER, R.; VAN DONSELAAR, K.; OUWEHAND, P. (2004) How to use aggregation and combined forecasting to improve seasonal demand forecasting. International Journalof Production Economics, v. 90, p.151-167.

DIAS, M. A. P. (1990) Administração de materiais: uma abordagem logística. São Paulo: Atlas.

DIAZ, C. A. P.; PIRES, S. I. R. (2003) Variação da Demanda ao Longo da Cadeia de Suprimentos: O Efeito da Amplificação da Demanda, XXIII Encontro Nacional de Engenharia de Produção. Ouro Preto/MG.

EAVES, A.; KINGSMAN, B. (2004) Forecasting for the ordering and stock-holding old spare parts. Journal of the Operation Research Society, v. 50, p.431-437.

GIL, A. C. (2008) Como elaborar projetos de pesquisa. 4. ed. São Paulo: Atlas. KRAJEWSKI, L. J.; RITZMAN, L. P.; MALHOTRA, M. (2009) Administração da produção e operações. 8. ed. São Paulo: Pearson Prentice Hall.

MAKRIDAKIS, S. (1988) Meta forecasting: Waysof Improving Forecasting Accuracy and Usefulness. International Journal of Forecasting, v. 4, 1988, p.467-491. 
MAKRIDAKIS, S.; WHEELWRIGHT, S. C.; HYNDMAN, R. J. (1998) Forecasting: methods and applications. 3. ed. New York, USA: John Wiley \& Sons, p. 641.

NEUFELD, J. L. (2003) Estatística Aplicada à Administração usando Excel. $1^{\text {a }}$ ed., São Paulo: Prantice Hall.

PORRAS, E.; DEKKERR. (2008) An Inventory control system for spare parts at a refinery: an empirical comparison of different re-order point methods. European Journal of Operational Research, v. 184, p. 101-132.

REID, R. D.; SANDERS, N. R. (2005) Gestão de operações. Rio de Janeiro: LTC. SAMOHYL, R. W.; SOUZA, G. P.; MIRANDA, R. G.(2008) Métodos simplificados de previsão empresarial. Rio de Janeiro: Editora Ciência Moderna Ltda.

WANKE, P.; JULIANELLI, L. (2006) Previsão de vendas: processos organizacionais e métodos quantitativos e qualitativos. São Paulo: Atlas. 